\title{
Species at War? \\ The Animal and the Anthropocene ${ }^{1}$
}

Florian Mussgnug

\begin{abstract}
Environmental politics has become inextricably entwined with planetary deep time. This article calls for a reconceptualization of the relation between humans and nonhuman nature. It rejects the ontological singularity of the human, either as a biological species (homo) or as a planetary superagent (Anthropos) and argues for a perspective centred on companionship and shared vulnerability. Animal philosophy serves here to counter a growing tendency to generalise and address the human species at large, in the singular. The cultural force of the animal, it is suggested, stems from a productive tension between the abstract singular ("the Animal") and the unique specificity of each particular nonhuman other. In the context of Anthropocene studies, references to Anthropos follow a similar logic. The planetary future of humans cannot be deduced from any specific geopolitical context or expressed through universalizing categories. It must be understood, against the vertiginous backdrop of geological time, as a process of becoming: a complex set of material and semiotic practices shaping open-ended, transformative trajectories.
\end{abstract}

Keywords: Anthropocene, animal, anthropocentrism, environmentalism, ecology, posthumanism, Derrida, Gaia, extinction.

Friend, said the Rat, listen to me.

You called Earth, now Earth is speaking.

Günter Grass, The Rat. ${ }^{2}$

Over the past eighteen years, the concept of the Anthropocene - first proposed by atmospheric chemist Paul Crutzen and ecologist Eugene Stoermer - has developed a cultural life of its own. ${ }^{3}$ The idea that Earth left its most recent geological epoch, the Holocene, as a consequence of human action, is widely discussed and has reverberated powerfully across the arts, humanities and social sciences, inspiring debates, publications and works of art. Earth scientists have paid growing attention to political, economic, social and cultural structures, in a manner that cuts across established disciplinary boundaries and calls for a reconceptualization of the relation between humans and nonhuman nature. Similarly, many social scientists, philosophers and cultural critics have shifted 
the focus of their inquiries towards natural processes and forms - climate patterns, drought zones, glacier flows, loss of species and so on - that are affected by human activities and impinge upon them. ${ }^{4}$ As Jussi Parikka explains, the concept of the Anthropocene is perceived by a growing number of scholars as a challenge to the traditional humanities but also as "a useful trigger for a variety of approaches that are interested in the nonhuman and post-human". ${ }^{5}$ Beyond the specific expertise of earth scientists, the Anthropocene has become an important staging ground for controversies about environmental justice, the future of global capitalism and the political, economic and cultural causes and consequences of population growth, climate change and species loss. ${ }^{6}$

There is, of course, nothing new about the claim that human activity interferes with the forces of the natural world, and is guided and constrained by its processes. Since its earliest origins, the idea of human civilization - in its manifold historical and cultural declinations - has been virtually synonymous with the "cultivation" of nature, imagined either in terms of pious stewardship or as ruthless conquest. ${ }^{7}$ Long before the advent of modern industrialisation, ecologists warned against the devastating consequences of anthropocentric cultural and material practices, from agriculture and deforestation to the pollution caused by large urban centres. Since the turn of the Twentieth Century, environmentalist movements in North America and Western Europe have agitated against exploitative, growth-driven techno-industrialism and have sought alternative forms of social organization, in harmony with other species. More recently, environmental justice has become a major political concern in the global South, where eco-activists defend local (multispecies) communities and the importance of locally embedded traditions, frequently against the interest of international actors and the nation state. ${ }^{8}$ Modern ecological thinking, as historians of environmentalism have shown, emerged fully in the 1960s and 1970s, but had its ideological roots in much earlier movements, including British and German Romanticism. ${ }^{9}$ Its long temporal trajectory also reaches into our present, where ecological thinking continues to shape debates about the Anthropocene. ${ }^{10}$ James Lovelock's “Gaia Hypothesis", for example, has enjoyed a surprising second life in the growing literature about the Anthropocene, thanks 
to the interest of leading contemporary thinkers such as Donna Haraway, Bruno Latour and Isabelle Stengers. Once hailed as a doyen of environmentalism, Lovelock has intervened in recent debates to address the relevance of his early work to an age of rapidly unfolding, global ecological catastrophe. ${ }^{11}$ In this context, much attention has focused on the British geophysicist's most wellknown claim that Earth ("Gaia") functions as a self-regulating and evolving, complex system: "an opera [...] that has neither a score nor an ending, and is never performed twice on the same stage", in Bruno Latour's words. ${ }^{12}$

While the burgeoning environmentalist movements of the Seventies associated Gaia with notions of global harmony, vulnerability and maternal care, discussions of Lovelock's theory have since acquired a more menacing overtone. ${ }^{13}$ The advent of large-scale and potentially catastrophic climate change, according to Lovelock and his interlocutors, alerts us to the fact that the Earth System, at the dawn of the Anthropocene, has become more inscrutable, more difficult to control, and less suitable for the flourishing of human populations. In contemporary discussions, this condition is often expressed in a metaphorical language of conflict, which - like the environmentalism of the Seventies - draws inspiration from the anthropomorphic name that was suggested to Lovelock by the novelist William Golding. "Gaia", it has been claimed, is "fighting back" or "seeking revenge", or, in the words of philosopher Clive Hamilton, is engaged in a "power struggle" with humankind, and "attempting to pull us into its domain".14 Other theorists have employed different, but similarly drastic metaphors. "Even if the human species manages to reduce its ecological footprint drastically", warn historians Christophe Bonneuil and Jean-Baptiste Fressoz, "we will not have settled our accounts with Gaia".15 Focusing on metaphors of intrusion rather than violent conflict or debt, Isabelle Stengers describes Gaia as a fearful and devastating power that encroaches on numerous kinds and species - including homo sapiens - and threatens their survival. ${ }^{16}$ Similarly, for Donna Haraway, "Gaia does not and could not care about human or other biological beings' intentions or desires or needs, but Gaia puts into question our very existence, we who have provoked its brutal mutation".17 
Despite Lovelock's influence, the relationship between twentieth-century environmentalism and Anthropocene thinking remains a point of controversy. For philosopher Clive Hamilton, ecological thinking must be superseded and replaced by what he labels Earth System thinking: a new transdisciplinary and integrative approach, which assimilates the traditional earth sciences and life sciences. Unlike ecology, which studies the connections between organisms and species in a shared environment, Earth System thinking shifts the focus away from local and regional specificity and towards interconnected planetary cycles and forces. As Hamilton explains, "the Anthropocene is emphatically not a new name for a more intense phase of human disturbance of local and regional ecosystems" but captures "the qualitative leap from disturbances of ecosystems to disruption of the Earth System".18 In his most recent monograph, Defiant Earth: The Fate of Humans in the Anthropocene (2017), the Australian philosopher builds on this idea to sketch the outlines of what he describes as a New Anthropocentrism: a fresh political and cultural awareness of humanity's dangerous, exponentially growing powers and a critical engagement with our ability to alter and shape planetary processes. New Anthropocentrism, for Hamilton, is explicitly anti-humanist and runs counter to more familiar forms of normative anthropocentrism (humans are destined to be the planet's dominant creature) or techno-supremacism. According to the author of Defiant Earth, the Anthropocene marks a rupture in planetary history since, under its new conditions, the future of the planet and the life it supports are inexorably dependent on human agency. Humans find themselves at the centre of the Earth System, whether we like it or not. Anthropos, for Hamilton, has become a "planetary super-agent" (133), but "it" [sic] remains embedded in nonhuman nature and constrained by its processes: "a knot in the fabric of nature" (52; author's italics). In the context of an increasingly dangerous and unstable Earth System, Hamilton's New Anthropocentrism thus acquires a pervasively tragic connotation: as a species, we are gaining awareness of the fatal consequences of our collective errors (hamartia), just as our established social, scientific and moral paradigms are rendered obsolete by Gaia's growing hostility and unpredictability. 
Hamilton's dual critique of traditional, normative anthropocentrism and global capitalism - "monstrous anthropocentrism" in Hamilton's words - shares some important similarities with ecological thinking (43). Like many strands of Posthumanism, New Anthropocentrism rejects the abstract, interchangeable, autonomous individual of liberal moral-political theory and urges us to stretch the limits of our imagination towards a new sense of planetary responsibility. Earth is viewed, in both contexts, as a single, shared habitat: not a mere backdrop or context for human action, but a constitutive and active presence that must be included in all our deliberations. Despite these important similarities, however, Hamilton frames his considerations as a critique of environmentalism, especially with regard to two central points. First, he defends the ontological singularity of the human, not as a biological species (homo) but as a planetary super-agent (anthropos). Secondly, he argues that exclusive attention to geochronology must replace the socio-economic and cultural focus of traditional historiography. For Hamilton, "the natural world inherited by modernity is gone, and all of the ideas built on it now float on its memory" (38). In the context of Defiant Earth, this applies not only to the apologists of predatory capitalism, but to anybody who continues to pay attention to patterns of social and economic inequality. What is required, according to Hamilton, is not a more nuanced socio-political critique of the period from around 1945 notoriously described by Paul Crutzen as the "Great Acceleration" - but an entirely new, mythopoetic account of humanity's tragic ascendency to unprecedented levels of protean, planetary power: “a story penned by geohistorians, attempting to tell the story of powerful beings soon to be overwhelmed by more powerful forces" (128). Questions of regional inequality or specific political responsibility, the Australian philosopher contends, are ultimately of secondary importance.

Hamilton's polemic, it appears, is specifically directed against left-wing thinkers like sociologist Jason Moore, who view climate change as a product of late capitalist industrial civilization - the "Capitalocene" - and who claim that the threat of global environmental catastrophe cannot be tackled independently from the inequalities and violence inscribed in the current global political and 
economic order. ${ }^{19}$ Versions of this idea are popular among environmental activists, climate justice movements and postcolonial theorists, and have also inspired Donna Haraway's "Chthulucene": a neologism that seeks to highlight the political violence inherent in any anthropocentric thought system. ${ }^{20}$ As the North American feminist has stressed in a recent contribution, "outrages meriting names like Anthropocene or Capitalocene are about socio-ecologically, historically situated human beings (not humankind all the time everywhere) destroying places and times of refuge for people and other critters". ${ }^{21}$

Hamilton's disagreement with Haraway and Moore is apparent, but his vision of two allegedly antagonistic and ideologically opposed camps - Posthumanism vs. New Anthropocentrism - misrepresents the cross-disciplinary openness of Anthropocene Studies. While Hamilton views human historiography per se as a misrepresentation of the advent of the new geological epoch, other scholars have called for a dual, historical and geological perspective, based on knowledge exchange, dialogue and cross-disciplinary inquiry. ${ }^{22} \mathrm{~A}$ recent project led by climatologists Simon Lewis and Mark Maslin, for example, defines the Anthropocene in relation to the complex environmental changes brought about by colonialism and transcontinental trade, especially at the level of introduced diseases, species exchange and forced human migration. ${ }^{23}$ In a different but related attempt to mark historical specificity, archaeologists Jon Erlandson and Todd Braje have dated the beginnings of the Anthropocene back to the domestication of plants and animals, some 10.000 years ago. ${ }^{24}$ Like Haraway's and Moore's critique of the Anthopocene, these projects signal a wider need to resist what historians Christophe Bonneuil and Jean-Baptiste Fressoz have labelled the "geocratic grand narrative of the Anthropocene", or rather, the claim that geochronology naturalizes and depoliticizes human history, and ultimately renders it irrelevant. ${ }^{25}$

When earth scientists discuss the human impact on Earth as a single, interlocked feedback system, they often turn their attention to deep time and the distant future. From a strictly stratigraphic point of view, the nuclear explosions of 1945 are perhaps the sharpest marker of human interference, since the sudden 
deposition of radionuclides across the Earth's surface will be easy to detect in the rock record even a hundred million years hence. ${ }^{26}$ The rapid increase in the concentration of carbon dioxide in the atmosphere, however, is likely to have much greater effects on the future of Earth, that are also less easy to predict. Other human activities, such as large reservoirs, megacities, deforestation and soil erosion will also affect Earth over a time-scale of several thousand years and therefore, in all likelihood, long after the end of human history. In light of all this, it is hard to concur with Hamilton's claim that a detailed knowledge of political, economic and social history is irrelevant to our understanding of the Anthropocene. Traditional Earth history does not focus on homo sapiens, which has walked the planet for a trifling 200,000 years, but when it comes to the Anthropocene, historical and geopolitical factors, including class, ethnicity and gender, must be taken into account. In this context, the political responsibility of social scientists and scholars in the arts and humanities, as Bonneuil and Fressoz point out, consists in fostering a sense of historical and cultural specificity: "To forget past reflections and understandings, struggles and defeats, illusions and mistakes, would mean losing an experience that is precious for the present challenges". 27

Human-Animal Studies, I suggest, provides a suitable framework for these discussions. Animal philosophy - in the tradition of Gilles Deleuze, Jacques Derrida and Donna Haraway - has long explored and critiqued the connection between anthropocentrism and biopolitical atrocity. As Rosi Braidotti explains, the animal has featured prominently in the long cultural history of the West, indexing the European subject's relation to otherness:

The metaphysics of otherness rested on an assumed political anatomy, implicitly modelled on ideals of whiteness, masculinity, normality, youth, and health. All other modes of embodiment, in the sense of both dialectical otherness (nonwhite, nonmasculine, nonnormal, nonyoung, nonhealthy) and categorical otherness (zoomorphic, disabled, or malformed), were pathologized and cast on the other side of normality that is, viewed as anomalous, deviant, and monstrous. This morphological 
normativity was inherently anthropocentric, gendered, and racialized. It confirmed the dominant subject as much in what he included as his core characteristics as in what he excluded as other. ${ }^{28}$

In his influential long essay, The Animal That Therefore I Am (2008), Jacques Derrida makes a similar point when he describes the "carnophallogocentric" character of European philosophy and modern, industrialised civilization. Twenty-first-century humans, writes Derrida, are no less dependent upon animal products than their ancestors in the eighteenth century. Indeed, our dependence has extended to demographic level unknown in the past, and to new fields: the industrial production of animal meat for consumption, biomedical research, more and more audacious manipulations of the genome, and so on. These contemporary uses of animals, however, are increasingly invisible. Animals are hidden away in laboratories and factory farms, slaughtered at mass disassembly plants and transformed into sanitised packages of meat: "visible in mediated form, but largely absent from our daily lives", in Shirley Vint's words. ${ }^{29}$ The deplorable conditions of non-human animals, as Derrida drily remarks, are "all too well known", yet they must be hidden from our view, since we could not otherwise endure their immense suffering. ${ }^{30}$ For there can be no doubt, as Derrida points out, that the oppressive social order premised on animal suffering is unbearable, that it runs counter to our most basic and innate sense of a meaningful existence: "the human well-being of man" (25).

Considered from a moral standpoint, anthropocentrism, for Derrida, is above all a failure of the imagination. Human exceptionalism - the belief that humans are essentially different from all other species - is a dogmatic slumber, that makes us oblivious to the demands of biosocial kinship, which for the French philosopher find their most articulate expression in Jeremy Bentham's reflections on the suffering of animals:

The response to [Bentham's] question "Can they suffer?" leaves no room for doubt. In fact, it has never left any room for doubt; that is why the experience that we have of it is not even indubitable; it precedes the 
indubitable, it is older than it. No doubt either, then, of there being within us the possibility of giving vent to a surge of compassion, even if it is the misunderstood, or denied, held at bay (28).

Exceptionalist ideologies, Derrida contends, obscure the scandalous reality of animal suffering in research labs and in the food production system, but they also blind us to the unquestionable reality of biosocial compassion, and thus erase the possibility of human flourishing. Our daily violence towards animals, premised on ideas of humanity's superior moral status, blocks any possibility of compassionate reciprocity, forgiveness, reconciliation and spiritual peace.

To make sense of the real presence of animals in our lives, Derrida contends, we must think beyond the pseudo-concept of "the Animal", used in the singular, as though all nonhuman species from the oyster to the chimpanzee constituted a homogenous set to which human beings are radically opposed. "The Animal”, for Derrida, epitomizes our species' carnophallogocentric desire for mastery, which he claims is embraced and taken for granted by Western philosophers from Aristotle to Heidegger. As Aaron Gross intimates: "When the reality of animals becomes 'the animal' - that is, a foil and shadow of the human - an opportunity arises, which may or may not be actualized, to forget animals themselves". ${ }^{31}$ For Derrida, this potential "absenting of animals" - our actual, existing fellow creatures - finds its logical and moral counterpoint in a utopian desire for the absence of "the Animal", understood as an abstract category. At a lexical level, this utopian longing is marked by Derrida's neologism animot: a word which, when spoken in French, recalls the extreme diversity of actual animals (animaux) that the abstract category erases, but that also makes us aware, in a typically Derridean shift of signification, that we inevitably depend on the abstract singular (Animal) which is nothing more, precisely, than a word (mot). As philosopher Andrew Benjamin has pointed out, the tension between universality and particularity cannot be resolved, but must be understood as a productive tension for narrative and the figurative arts: the abstract singular threatens to erase the particular, but it is also threatened by particularity: "the actual existence of those figured". 32 
Derrida's robust critique of carnophallogocentric philosophy echoes profoundly in contemporary human-animal studies, through the works of influential thinkers such as Ralph Acampora, Matthew Calarco, Kelly Oliver and Cary Wolfe, among others. This influx of new voices and visions, across disciplines, has profoundly altered our understanding of animal welfare, moving away from the notion of animal rights - in the analytic tradition of Peter Singer, Mary Midgley and others - and towards a new idiom centred on companionship, shared vulnerability and a sense of humanity that is always established in relation to animality. In the context of Anthropocene studies, this tradition may now serve, as Ursula Heise and others have suggested, to counter a growing tendency among commentators to generalise and address the human species at large, in the singular:

This conceptual move tends to come easily to natural scientists, who often lump all humans together so as to highlight their differences from or interactions with other species and natural environments. It is a much more difficult move for social scientists and humanists, to whom historical, social, and cultural differences between communities tend to stand out much more sharply. ${ }^{33}$

Historians, social scientists and scholars in the environmental humanities, according to Heise, are well placed to interrogate seemingly unproblematic references to humanity in Anthropocene discourse. William Connolly, in Facing the Planetary: Entangled Humanism and the Politics of Swarming, (2017), concurs with this idea. "I oppose any sense of generic human responsibility for the contemporary planetary condition", explains Connolly. "Generic responsibility must be replaced by regionally distributed responsibilities and vulnerabilities" and the role of the scholar, in this respect, must be "to face the planetary while connecting that face to regional, racial, and urban issues with which it is imbricated". ${ }^{4}$ Scholars in the humanities, he argues, must engage with the specific expertise of geologists, glaciologists, climatologists, and palaeontologists, in a broad merger of intellectual and political efforts. This mutual partaking in 
specific areas of disciplinary knowledge, however, must not be imagined as a one-way process, but needs to be understood, according to Connolly, as a form of entanglement: "The preciousness of classical humanism must be challenged by what I call entangled humanism". ${ }^{35}$ Similarly, Stacy Alaimo has acknowledged the need to address human responsibility on a vast and predominantly geological, temporal and spatial scale, but has warned that this must not stand in the way of swift political action, in response to environmental degradation. Citing the case of the deep sea, Alaimo calls for a scholarly perspective that beholds both the expansiveness of geological time and the "eerie temporal compression" of anthropogenic climate change, and that acknowledges the resultant devastation of species, habitats and entire ecosystems:

Whereas the ability to stand back and map vast terrains-the already emblematic epistemological stance of the Anthropocene-places Man outside of that which he surveys, the compressed time of the Anthropocene seas puts us under pressure, weighs us down with the recognition that even as human impacts may be colossal, human understanding of marine ecologies and species, especially those of the deep seas, is miniscule. ${ }^{36}$

This sense of humility, as Michelle Niemann has shown, constitutes an increasingly important paradigm for scholars in the environmental humanities, and links their efforts to earlier work by environmental activists and ecocritics. ${ }^{37}$

I have argued that the cultural force of the animal stems from a productive tension between the abstract singular ("the Animal") and the unique specificity of each particular nonhuman other. Exclusive attention to either phenomena, according to Derrida, would be inevitably reductive. In the context of Anthropocene studies, references to the human follow a similar logic. If we treat Anthropos as an abstract singular ("the Human"), historical and geopolitical distinctions risk to disappear from sight, as do differences of class, ethnicity and gender. By contrast, if we focus our attention on specific historical events, we may fail to grasp the vertiginous scale of what Hamilton calls the "rupture in the 
functioning of the Earth System". ${ }^{38}$ In order to engage with both temporal levels - history and planetary deep time - we must envisage the human, similarly to the animal, as a figuration: a complex set of material and semiotic practices, whose open-ended, transformative trajectories cannot be fully addressed through universalizing categories. The cultural force of the animal is only partly located in any specific nonhuman other, and accrues power and value across multiple figurations. Similarly, the planetary future of Anthropos cannot be deduced from any particular geopolitical context, and must be understood as a process of becoming. Derrida's metaphorical description of human-animal relations as a "war for compassion", which I now turn to, offers an interesting illustration of this idea.

For two centuries, Derrida writes, we have been at war: a war waged by homo sapiens against other species, but also "between, on the one hand, those who violate not only animal life but even and also this sentiment of compassion, and, on the other hand, those who appeal for an irrefutable testimony to this pity". ${ }^{39}$ This long war, Derrida surmises, "is probably ageless but, and here is my hypothesis, it is passing through a critical phase". ${ }^{40}$ In the context of Anthropocene studies, Derrida's allusions to an escalating conflict recall concerns about biodiversity and the potential collapse of important ecosystems. Extinction rates have grown disproportionately in recent decades, as a result of habitat destruction, invasive species, pollution, human population growth and overharvesting. Evolutionary biologists have warned that a mass extinction of species - only the sixth to occur in the 3.5 billion years of life on Earth - may be taking place in our age, as a result of human activities. As Ursula Heise explains, conservationists have struggled to convey this development to non-specialist audiences, whose compassionate interest is triggered mainly by large, vaguely anthropomorphic mammals: "flagship species" or "charismatic megafauna". ${ }^{41}$ Derrida, by contrast, focuses his attention on domestic animals and factory farming, but opts for a similarly melodramatic register. As historian Aaron Gross explains, "it would be a mistake to take Derrida's use of the word war as strictly metaphorical. Like the conventional use of the term war, it signals an immense 
mobilization of resources, social (local, regional, national, global) planning, an intensified use of technologies, destruction of environments, and mass killing". ${ }^{42}$

At the most literal level, the French philosopher's idea of a never-ending war between species brings to mind narratives like the Planet of the Apes series (since 1968) or Günther Grass' dark and exhilarating Die Rättin [The Rat, 1986] in which the eponymous rodents trigger a nuclear war that entirely wipes out homo sapiens. As Sheryll Vint has shown, many works of apocalyptic science fiction imagine "a recurrence of war with fellow creatures, human and nonhuman; the threat of human annihilation and a vision - sometimes fearful, sometimes optimistic - about another species replacing us as the dominant form of life". 43 More frequently still, animals feature in the aftermath of imagined manmade catastrophes, as inhabitants and symbols of a post-apocalyptic "world without us" - a tradition that goes back to Richard Jeffrey's Darwinian neo-feudal romance After London or Wild England (1885) and that spans languages and cultures. Italian readers, for example, may find compelling examples of the genre in Guido Morselli's Dissipatio H.G [Dissipatio H.G., 1977], Paolo Volponi's Il pianeta irritabile [Irritable Planet, 1978] and Carlo Cassola's Il superstite [The Survivor, 1978]. More widely known instances of the same trope may be found in Terry Gilliam's Twelve Monkeys (1995), where a lion and a bear are seen roaming the ruins of a post-apocalyptic Manhattan, or in the most recent, third cinematic adaptation of Richard Mathewson's I am Legend (1954): a film of the same title (2007), directed by Francis Lawrence, which includes scenes of a solitary dearhunt, again, in what used to be the cultural and financial centre of New York

Elegiac or melodramatic narratives of extinction, according to Heise, foster a nostalgic and pessimistic attitude, which is also increasingly common among conservationists. Two and a half decades after the Rio Earth Summit, most researchers and environmental activists concur that we can no longer prevent the catastrophic consequences of anthropogenic climate change, but can only hope to limit its pace and extent, and seek to adjust to the new conditions. ${ }^{44}$ Some have argued that we must learn to let go of certain species and ecosystems. ${ }^{45}$ As Donna Haraway points out, it has become difficult to maintain 
any hope for the future, or to perpetuate individual or collective efforts to improve the lives of human and nonhuman others. A "game-over attitude" appears sadly appropriate and yet, Haraway contends, "there is a fine line between acknowledging the extent and seriousness of the troubles and succumbing to abstract futurism and its affects of sublime despair and its politics of sublime indifference". 46 So does Derrida's bleak vision of a never-ending conflict between species strike the right balance between naïve hope and paralysing despair?

Our answer here depends crucially on the deliberate ambivalence of Derrida's formulation. The war between species, he claims, is "probably ageless": a conflict as old as the human indifference towards other animals. ${ }^{47}$ Yet Derrida's neverending war is not merely (and not primarily) a conflict between species. Indeed, such a reductive reading would return us, precisely, to the state of dogmatic blindness which the neologism animot seeks to disrupt. The apparent Manichean symmetry of Derrida's metaphor, then, dissolves into a powerful, albeit enigmatic demand for care, that unhinges abstract notions of alterity and sameness, premised on human exceptionalism. The war between species, Derrida claims, is ultimately a struggle against those who violate "the sentiment of compassion".

Can the war between species ever come to an end? Derrida's critique of carnophallogocentrism exposes the inherent contradictions of any desire for conceptual purity, arguing that species identity is always predicated on difference. For the French philosopher, the abstract singular ("the Animal") is meaningless without the heterogeneous multiplicity of the living, just as the specific nonhuman other cannot be fully grasped in the absence of general categories. The relation between animal life and the so-called human, writes Derrida is "at once intertwined and abyssal, and they can never be totally objectified". 48 With a slight shift of theoretical perspective, we can give a different meaning to Derrida's extended metaphor. Thinking beyond the logic of aporia, I suggest that the conflict between species can be put to rest, pace Derrida, by a radical reshaping of the human-animal bond. If we relinquish the 
tragic temporality of Derrida's war (or Hamilton's struggle with Gaia) in favour of new forms of posthuman vitality, we may find that biology itself offers a radical alternative to anthropocentrism. Our most radical hope for the future, according to this view, lies not in an imagined apocalyptic closure but in the perpetual self-transformation of life in all its forms: a force which transcends all existing social categories, boundaries and limits, and opens up our personal, social and cultural existence to endless becoming.

\section{NOTES}

${ }^{1}$ Some of the ideas contained in this article were presented during the three-day seminar "The Non-Human in World Literature", convened by Mads Rosendahl Thomsen, Dominique Jullien and Wen-chin Ouyang in the context of the ACLA's 2017 Annual Meeting hosted by the University of Utrecht. I am grateful to the three organisers and to all participants for their comments and suggestions.

2 "Freund, sagte die Rättin, hör zu. Erde hast du gerufen, hier spricht die Erde"; Günter Grass, Die Rättin (Munich: Luchterhand Literaturverlag, 1986) p. 67; my translation.

3 Paul J. Crutzen and Eugene F. Stoermer, "The Anthropocene", Global Change Newsletter, 41 (2000), 17-18.

${ }^{4}$ Timothy Clarke, Ecocriticism on the Edge: The Anthropocene as a Threshold Concept (London and New York: Bloomsbury, 2015); Peter Barry and William Welstead (eds), Extending Ecocriticism: Crisis, Collaboration and Challenges in the Environmental Humanities (Oxford and New York: Oxford University Press, 2017).

5 Jussi Parikka, "Anthropocene", in Braidotti and Hlavajova (eds), Posthuman Glossary (London and New York: Bloomsbury, 2018), 51-53 (p. 52). See also Jussi Parikka, The Anthrobscene (Minneapolis and London: University of Minnesota Press, 2014).

${ }^{6}$ Christophe Bonneuil and Jean-Baptiste Fressoz, The Shock of the Anthropocene, translated by David Fernbach (London and New York: Verso: 2015); Jason W. Moore (ed.), Anthropocene of Capitalocene? Nature, History and the Crisis of Capitalism (Oakland, California: PM Press, 2016).

7 Keith Thomas, Man and the Natural World: Changing Attitudes in England 15001800 (London: Penguin, 1983), 17-50; Jonathan Bate, The Song of the Earth (Cambridge, Massachusetts, and London: Harvard University Press, 2000). 
${ }^{8}$ Rob Nixon, Slow Violence and the Environmentalism of the Poor (Cambridge, Massachusetts, and London: Harvard University Press, 2011).

${ }^{9}$ Ramachandra Guha, Environmentalism: A Global History (New York: Longman, 1999); Joachim Radkau, Die Ära der Ökologie: Eine Weltgeschichte (Munich: C.H. Beck, 2011).

${ }^{10}$ For an interesting and comprehensive discussion of ecological thinking, see Lorraine Code, Ecological Thinking: The Politics of Epistemic Location (Oxford and New York: Oxford University Press, 2006).

11 James Lovelock, The Revenge of Gaia (London: Allen Lane, 2006).

12 Bruno Latour, Facing Gaia: Eight Lectures on the New Climatic Regime (Cambridge: Polity, 2017), p. 107.

13 Ursula K. Heise, Sense of Place and Sense of Planet: The Environmental Imagination of the Global (Oxford and New York: Oxford University Press, 2008), pp 22-24.

14 Clive Hamilton, Defiant Earth: The Fate of Humans in the Anthropocene (Cambridge: Polity Press, 2017), p. 45.

15 Bonneuil and Fressoz, Shock of the Anthropocene, p. 21.

16 Isabelle Stengers, In Catastrophic Times: Resisting the Coming Barbarism, translated by Andrew Goffey (London: Open Humanities Press/Meson Press, 2015).

17 Donna J. Haraway, Staying with the Trouble: Making Kin in the Chthulucene (Durham and London: Duke University Press, 2016), p. 44.

${ }^{18}$ Hamilton, Defiant Earth, pp, 12-13; my italics. Page numbers will appear in the article.

19 Moore, Anthropocene of Capitalocene?

${ }^{20}$ Haraway, Staying with the Trouble, p. 2.

${ }^{21}$ Donna J. Haraway, "Capitalocene and Chthulucene" in Braidotti and Hlavajova (eds), Posthuman Glossary, 79-83 (p. 80).

22 Jeremy Davies, The Birth of the Anthropocene (Oakland, California: University of California Press, 2016); J.R. Mcneill and Peter Engelke, The Great Acceleration: An Environmental History of the Anthropocene since 1945, (Cambridge, Massachusetts, and London: Harvard University Press, 2016).

23 Simon L. Lewis and Mark A. Maslin, "Defining the Anthropocene", Nature, 519 (2015), 171-80.

24 Jon M. Erlandson and Todd J. Braje (eds), When Humans Dominated the Earth: Archaeological Perspectives on the Anthropocene, Special Issue, Anthropocene, 4 (2013).

25 Bonneuil and Fressoz, Shock of the Anthropocene, p. 45.

26 Jan Zalasiewicz, The Earth After Us: What Legacy Will Humans Leave in the Rocks? (Oxford and New York: Oxford University Press, 2008). 
27 Bonneuil and Fressoz, Shock of the Anthropocene, p. xiii.

28 Rosi Braidotti, "Animals, Anomalies, and Inorganic Others", PMLA, 124: 2 (2009) 526-32 (p. 526).

${ }^{29}$ Sherryl Vint, Animal Alterity: Science Fiction and the Question of the Animal (Liverpool: Liverpool University Press, 2010), p. 1.

30 Jacques Derrida, The Animal That Therefore I Am, English translation by David Wills (New York: Fordham University Press, 2008), p. 25. Page numbers will appear in the article.

31 Aaron Gross, The Question of the Animal and Religion: Theoretical Stakes, Practical Implications (New York: Columbia University Press, 2015), pp. 187-88.

${ }^{32}$ Andrew Benjamin, Of Jews and Animals (Edinburgh: Edinburgh University Press, 2010), p. 5.

33 Ursula K. Heise, Imagining Extinction: The Cultural Meanings of Endangered Species (Chicago: University of Chicago Press, 2016), p. 220.

34 William E. Connolly, Facing the Planetary: Entangled Humanism and the Politics of Swarming (Durham and London: Duke University Press, 2017), p. 33.

35 Connolly, Facing the Planetary, p. 33; author's italics.

36 Stacy Alaimo, "The Anthropocene at Sea: Temporality, paradox, compression", in Ursula K. Heise, Jon Christensen and Michelle Niemann (eds), The Routledge Companion to the Environmental Humanities (London and New York: Routledge, 2017), 153-61 (pp. 153-54).

37 Michelle Niemann, "Hubris and humility in environmental thought", in Heise, Christensen and Niemann (eds), Companion to the Environmental Humanities, 247-57.

${ }^{38}$ Hamilton, Defiant Earth, p. 10.

39 Derrida, The Animal, pp. 28-29.

40 Derrida, The Animal, p 29.

${ }^{41}$ Heise, Imagining Extinction, p. 25.

42 Gross, The Question of the Animal, pp. 131-32.

43 Vint 2010, Animal Alterity, p. 208.

${ }^{44}$ Dale Jamieson, Dale, Reason in a Dark Time: Why the Struggle against Climate Change Failed and what it means for Our Future (Oxford and New York: Oxford University Press, 2014).

45 Peter Kareiva and Michelle Marvier, "What Is Conservation Science?"

BioScience, 62:11 (2012), 962-69.

46 Haraway, Staying with the Trouble, 4.

47 Derrida, The Animal, p. 29.

48 Derrida, The Animal, p. 31. 